\title{
O aprendizado da violência: o Amigo, o Idiota e o Mestre-Escola no plano de Deleuze e Guattari
}

Eraldo Souza dos Santos

\begin{abstract}
Ao primeiro ano do Bialik, sine qua non. À senhorita de Weber, por sua crítica precisa e impiedosa ao tom professoral dos professores. Ao senhor Cohn, por sua crítica precisa e impiedosa aos professores que insistem em ensinar como escolásticos.
\end{abstract}

\section{Resumo:}

O presente ensaio busca reunir materiais para dar conta da seguinte questão: por que a figura do aprendizado violento é tão recorrente na exposição deleuziana do conceito de filosofia e de imagem do pensamento? Para tanto, analisaremos fundamentalmente dois textos do autor: Proust e os signos (I964) e O que é a filosofia? (I99I), esse segundo escrito em parceria com Félix Guattari. No "plano de imanência" de "Deleuze-Guattari", violência, aprendizado e pensamento são conceitos inseparáveis, fundamentais para empreender uma crítica à filosofia tradicional e para construir uma nova imagem do pensamento. A escolha por "personagens conceituais" como o Mestre-Escola e o Amigo da sabedoria ("personagens antipáticos") e como o Idiota, o Amante, o Artista e o Amigo-Rival ("simpáticos") resulta na criação-construção de um plano de imanência sobre o qual a filosofia só pode ser pensada como trabalho da violência, jamais como simples resultado da boa vontade do pensador. Palavras-chave: violência - aprendizado - imagem do pensamento - Idiota Mestre-Escola 
[...] é preciso não esquecer e respeitar a violência que temos. As pequenas violências nos salvam das grandes. [...] É preciso acreditar no sangue como parte importante da vida. A truculência é amor também. (Glarice Lispector, Um aprendizado ou O livro dos prazeres)

\section{Violência}

É preciso ser dotado para os signos, predispor-se ao seu encontro, expor-se à sua violência.

(Gilles Deleuze, Proust e os signos)

A conhecida frase de Deleuze, exposta logo ao fim da primeira parte de sua monografia Proust e os signos, arremata um percurso argumentativo que procura mostrar que o aprendizado é um processo que não pode ser pensado em separado de uma necessária violência. Mas não se trata somente, lá, naquele texto, de um aprendizado em geral, mal localizado: precisamente demarcado, o campo do aprender envolve necessariamente a atividade de coação, sobre nossa placidez, daquilo que é, para cada um de nós, o outro, o imediatamente diferente, o que nos surpreende quando surge para nós em encontros contingentes, e que motiva o pensamento a iniciar o seu trabalho. Mais precisamente, para usar uma expressão cara a Deleuze, a julgar pela quantidade de vezes que a repete em tão curto espaço textual: isso, que é a alteridade imediatamente contrastante em relação a nós, que nos força a pensar.

É justamente ao colocar sobre um mesmo plano aprendizado, pensamento e violência que Deleuze buscará construir o que chama de uma nova imagem do pensamento, o que significa uma nova imagem da filosofia. Mas para traçar a imagem tradicional, da qual deseja se desvencilhar, o filósofo mostra os personagens antipáticos que a ela se ligam a seu ver - a figura do Mestre-Escola e do professor e a figura sempre elogiada e distante do filósofo como "amigo da sabedoria". Não é senão por causa dessa antipatia que tal nova imagem é buscada justamente fora do campo da filosofia tradicional - não é à toa que ela será tratada e traçada numa monografia sobre arte, como Proust e os signos. A arte oferecerá uma nova forma de pensar a filosofia e à filosofia. Não se trata de unir arte e filosofia, mas de mostrar que ambas têm em comum o fato de serem atividades criadoras; a criação da filosofia, todavia, tem uma especificidade: ela é a atividade de criação de conceitos. Trata-se de uma maneira peculiar de dar forma ao adágio kantiano - se "não se ensina filosofia, ensina-se a filosofar", é porque a atividade filosófica é necessariamente criadora, e, se é criadora, é justamente porque está aberta aos encontros com o mundo, porque está aberta 
para a violência. Aprender filosofia, nesse ínterim, é tornar-se progressivamente dotado para isto que nos violenta nas coisas - os signos que elas emitem.

$\mathrm{O}$ que queremos investigar brevemente neste trabalho é a maneira como Deleuze, para conceber sua imagem do pensamento (algo que todos os filósofos fazem, cada um a seu modo) recorre, como "materiais" fundamentais para a construção dessa concepção, às figuras do aprendizado e do ensino. Cremos que não se trata de uma tentativa de forçar uma interpretação violenta à obra do filósofo. Nem de buscar encontrar nela uma teoria do aprendizado pronta a ser aplicada, transformando em manual algo que na obra dos autores apareceria disperso e mal sistematizado. Não. Para usar termos do próprio autor, tratar-se-á de se perguntar: por que os conceitos de aprendizagem e ensino são tão fundamentais em sua obra? E por que personagens antipáticos como o Mestre-Escola, o Professor, o Idiota e mesmo o filósofo ocupam tamanho espaço no seu plano conceitual ou plano de imanência? Por que ir em direção à filosofia significa passar por todas essas figuras ligadas à atividade do aprender? Para empreendermos essa reflexão, dirigir-nos-emos fundamentalmente para dois textos: Proust e os signos e $O$ que é a filosofia?, esse escrito em parceria com Félix Guattari.

Percorrer esse caminho possibilitará que esbocemos reflexões a partir de um duplo olhar. Em primeiro lugar, poderemos nos perguntar em que sentido a reflexão sobre o que é o pensamento passa necessariamente por uma reflexão sobre o que é o aprendizado. E por que, no sentido inverso, uma reflexão sobre o que é o aprendizado passa necessariamente por uma reflexão sobre o que é o pensamento. Em segundo lugar, haverá espaço para que nos indaguemos por que a violência é algo inerente ao aprendizado - e também, inversamente, porque o aprendizado é algo inerente à violência. Decerto existem muitos estudos científicos que tratam desses temas, estudando os aspectos cognitivo e afetivo do aprendizado. Aqui, concentrar-nos-emos em algo como um "aprendizado filosófico" em suas especificidades, tal como a filosofia busca entendê-lo - o que aprendo com filosofia, o que se aprende com a filosofia, o que a atividade do pensamento gostaria de nos ensinar (se gostaria...)? A pergunta de Deleuze - $O$ que nos força a pensar? - nesse ínterim, servirá como guia para que nos orientemos diante das relações entre filosofia, aprendizado, pensamento e violência. Diferentemente de estudos como os de Bianco $(2002 ; 2005)$, que são uma das bases fundamentais deste trabalho, nosso esforço se concentrará em abordar a questão do aprendizado em Deleuze nem tanto a partir dos conceitos fundamentais que a rodeiam, como "pedagogia do conceito" e "desterritorialização". Mas sim a partir dos personagens conceituais que "interpretam" e dão movimento a tais conceitos. 


\title{
II. Aprendizado
}

\author{
Quem procura a verdade é o ciumento que descobre um signo mentiroso \\ no rosto da criatura amada; é o homem sensivel quando encontra a violência \\ de uma impressão; é o leitor, o ouvinte, quando a obra de arte emite signos, \\ o que o forçará talvez a criar, como o apelo do gênio a outros gênios. \\ (Gilles Deleuze, Proust e os signos)
}

A Recherche não é, como a tradição da teoria literária quer nos fazer acreditar, "exposição de uma memória involuntária" (DELEUZE, 2003, p. 3), mas sim "relato de um aprendizado" (ibidem). Trata-se, do ponto de vista dos estudos que se dirigem à obra de Proust, de uma inovação: Deleuze encara a busca do tempo perdido como projeção para o futuro, e não como simples retorno através da memória involuntária ao passado que se perdeu e que de repente retorna. Tal projeção é precisamente o que torna a memória instrumento do aprendizado: "aprender é ainda relembrar; mas por mais importante que seja o seu papel, a memória só intervém como o meio de um aprendizado que a ultrapassa tanto por seus objetivos quanto por seus princípios. A Recherche é voltada para o futuro e não para o passado" (ibidem, p. 4).

Mas, se aprender está vinculado à memória é precisamente porque só a memória nos possibilita recuperar os signos que apreendemos no passado. E é justamente através dos signos que o aprendizado se constitui - "aprender diz respeito essencialmente aos signos" (ibidem, p. 4). Quem aprende é como um egiptólogo - "não existe aprendiz que não seja 'egiptólogo' de alguma coisa" (ibidem), "o egiptólogo, em todas as coisas, é aquele que faz uma iniciação - é o aprendiz" (ibidem, p. 86). Aprendiz é sempre aquele que se inicia no mundo dos signos: sua busca é busca dos e abertura para os signos, saída à procura de "tudo [o que] existe nessas zonas obscuras em que penetramos como em criptas, para aí decifrar hieróglifos e linguagens secretas" (ibidem).

Ir de encontro aos signos é necessariamente, por sua vez, interpretá-los. A verdade, nesse ínterim, não se descobre a não ser por interpretação, decifração dos signos. O percurso do aprendizado se define precisamente pelo progressivo contato com os signos, pela necessária interpretação de tais signos. Se essa interpretação é necessária, constituindo-se como atividade involuntária e nem sempre consciente, é porque a violência dos signos, como poderemos ver, não abre espaço para outra reação do aprendiz que não a interpretação.

Vale notar que signo, aqui, não coincide exatamente com aquela realidade à qual o linguista se refere. Não é necessário, dentro do quadro deleuziano, para compreender a natureza do signo, que o fragmentemos em elementos ou 
dimensões, que o analisemos em signo, significante e significado. Porventura o signo não seja mônada - talvez seja realidade partida. Mas isso não é o essencial. O essencial no signo é a sua violência. O signo é o que surge e nos choca, que nos força a nos deslocar, que nos obriga a pensar - tão simples e violento quanto isso. Não há "função" para o signo, ele não tem como objetivo assegurar a boa comunicação, pacífica e segura, entre o eu e os outros, entre o eu e o mundo. Tal caráter não comunicativo do signo, importante ressaltar, está estreitamente ligado ao ataque deleuziano às disciplinas da comunicação - viver com os outros não é comunicar-se, buscando o consenso, de boa vontade; o debate filosófico, muito menos (BIANCO, 2002, p. I80; 192). Se o signo comunica algo, o que ele comunica são intensidades, porque transmite a violência entre os seres. Interpretamos tais signos, porque sua violência exige de nós e para nós uma explicação. O signo, por sua vez, não comunica qualquer coisa que está transcendente a si mesmo (um significado, uma essência, uma Ideia...), ele comunica-se a si próprio. Daí o caráter imanentista da teoria deleuziana do signo - "o signo não significa alguma coisa de transcendente, mas exprime ou envolve alguma coisa, a Ideia não está à espera de que a colhamos" (ibidem, p. I90).

Os signos, todavia, não são todos iguais. Podemos classificá-los. O texto deleuziano nos obriga a todo o momento a interpretar se essa é uma divisão dos signos em geral ou uma divisão específica para a obra de Proust. Trata-se, no fundo, das duas alternativas. O escritor teria conseguido melhor do que qualquer filósofo pôr em jogo todos os tipos de signos, explicitando seus impactos, suas consequências e sua relação com a verdade. Deleuze, por sua vez, os classifica, para deles extrair um aprendizado, aprendizado que o fim da Recherche traz.

Em primeiro lugar, temos os signos mundanos, que são signos vazios; pretendem valer por seu sentido próprio e são suficientes; por isso, substituem ação e pensamento. São os signos dos circunlóquios, dos salões, dos sofás, das modas. Do ponto de vista das ações, são cruéis; do ponto de vista do pensamento, estúpidos (ibidem, p. 6) - "nada engraçado é dito em casa da Sra. Verdurin e esta não ri, mas Cottard faz sinal de que está dizendo alguma coisa engraçada, a Sra. Verdurin faz sinal de que ri e este signo é tão perfeitamente emitido que o Sr. Verdurin, para não parecer inferior, procura, por sua vez, uma mímica apropriada" (trecho de Le Côté de Guermantes, apud ibidem). Gestos vazios, enganadores, estereotipados... inúteis? Não: sua vacuidade, embora aparentemente desprezível, confere a esses signos o formalismo de uma perfeição ritual. Sem eles, o aprendizado seria imperfeito e mesmo impossível.

Os signos amorosos, por sua vez, estão ligados necessariamente à paixão. Apaixonar-se é individualizar o ser amado através dos signos. Todo amado 
implica um novo mundo, "aprisiona um mundo" (ibidem, p. 7), um mundo possível que é preciso interpretar e decifrar. Amar, nesse sentido, "é procurar explicar, desenvolver esses mundos desconhecidos que permanecem envolvidos no amado" (ibidem). O movimento se inverte - o mundo não é mais somente uma paisagem que vemos, mas também a paisagem em que somos vistos (ibidem). Tal é uma alteração extremamente violenta. Passamos a ser, nessa paisagem do ser amado, mais uma das figuras, só mais um mundo possível. Desconheço os outros amantes que meu amado já teve e, por isso e por muito mais, o amado implica um mundo desconhecido, que me exclui. Desejo que todas as carícias, gestos e preferências do amado sejam dirigidos para mim. Mas não são. A cada momento que o amado mostra sua preferência por mim, imediatamente conjecturo todos os mundos possiveis em que eu não seria o preferido, em que não fui efetivamente o preferido. O amor, inexoravelmente, prepara seu fim. A verdade do amor só pode ser pensada a partir do ciúme e nisso se constitui a contradição do amor: os meios que temos para nos protegermos do ciúme são os meios que levam diretamente ao desenvolvimento desse sentimento, dando a ele uma independência em relação a nosso amor.

Mas logo o ciúme, como se fosse a sombra de seu amor, se completava com o double desse novo sorriso que ela lhe dirigira naquela mesma noite - e que, inverso agora, escarnecia de Swann e enchia-se de amor por outro... De sorte que ele chegou a lamentar cada prazer que gozava com ela, cada carícia inventada e cuja doçura tivera a imprudência de lhe assinalar, cada graça que nela descobria, porque sabia que dali a instantes iriam enriquecer de novos instrumentos o seu suplício (trecho de Du coté de chezSwann, apud ibidem, p. 8).

O ciúme é sempre uma busca pela verdade. Ele é mais profundo do que o amor, contém a verdade do amor, a sua finalidade e a sua destinação (ibidem, p. 8). É mais profundo justamente porque vai mais longe na interpretação dos signos. Isso é simplesmente inevitável - o amado implica outros mundos que me excluem; mundos que o amado não pode, não quer revelar. Os signos do amor incomodam por serem signos da mentira - quando se dirigem a nós, sabemos que escondem algo. E nossa busca por esse algo é incessante. Descobrir que no fundo não éramos amados (como imaginávamos!) é a máxima perda e o máximo triunfo, pois se goza de algo com essa verdade ("eu sabia!"), algo que intimamente desejávamos. O verdadeiro, aqui, não é da ordem do superficial e do estereótipo, mas do profundo - os signos do amor "não suscitam uma exaltação nervosa superficial, mas o sofrimento de um aprofundamento. As mentiras do amado são os hieróglifos do amor. O intérprete dos signos 
amorosos é necessariamente um intérprete de mentiras. O seu destino está contido no lema 'Amar sem ser amado"” (ibidem, p. 9). Mas podemos lutar para recuperar o nosso amado, que se perdeu e agora goza de prazeres e festas com outro, outra, outros, outras...? Não - porque não conhecemos esses outros mundos possíveis. "O rival não era semelhante a mim, suas armas eram diferentes, eu não podia lutar no mesmo terreno, proporcionar a Albertina os mesmos prazeres, nem mesmo concebê-los de modo exato" (trecho de Sodomme et Gomorrhe, apud ibidem, p. 9). O amado, através dos signos que emite, provoca-nos uma violência. É a violência da mentira. Violência que nos força a buscar a verdade, por mais dolorosa que ela possa ser.

Já os signos sensiveis são verídicos; proporcionam-nos uma estranha alegria. Lembramos, através deles, do que a princípio era um simples signo vazio ou corriqueiro. Revelam objetos ocultos - através da madeleine, Combray retorna. Mas entender o que se passa na lembrança de tais signos oferece dificuldade. Tal dificuldade não reside no esforço de compreender como vem à tona a lembrança que o personagem tem da madeleine, de Combray, da infância; mas de entender porque, de alguma maneira, tal lembrança traz uma alegria tão particular e vivaz, um pedaço da eternidade, que não foi vivido jamais em nenhum momento do passado, quando os signos agora relembrados eram de uma simplicidade plácida. Eu não era tão alegre, naqueles tempos, enquanto comia aquele doce, enquanto passeava por aquelas calçadas; mas, agora, que me recordo disso, sou invadido por uma alegria inexplicável. Mas não é só alegria que tais signos nos trazem - lembram-nos de coisas igualmente simples, mas que nos sensibilizam para a passagem do tempo e para a decadência dos seres. Lembrar-se das botas velhas de nossa vó, a princípio, é uma lembrança alegre; mas a nossa vó morreu: e então, o que as botas trazem é a angústia da dissolução das coisas no nada.

O percurso do aprendizado termina com os signos da arte, que são propriamente aqueles para os quais o aprendizado nos direciona no percurso da Recherche. A arte nos apresenta signos imateriais e um sentido espiritual. Através dela superamos a contingência do mundo. Trata-se da figura que recupera o tempo perdido.

Só pela arte podemos sair de nós mesmos, saber o que vê outrem de seu universo que não é o nosso, cujas paisagens nos seriam tão estranhas como as que porventura existem na Lua. Graças à arte, em vez de contemplar um só mundo, o nosso, vemo-lo multiplicar-se, e dispomos de tantos mundos quantos artistas originais existem, mais diversos entre si do que os que rolam no infinito... (trecho de Les temps retrouvé, apud ibidem, p. 40). 
Os signos artísticos superam a vacuidade, a mentira e a oscilação - características dos outros signos - entre o que sobrevive e o nada. Deleuze aposta justamente nesse tipo de signo ao fazer sua a noção proustiana de aprendizado. É através dos signos artísticos que, num jogo entre a diferença e a repetição, a atividade artística, criadora, violenta, dá forma à multiplicidade do mundo, mantendo-o em sua diversidade característica ao mesmo tempo em que torna possível captá-lo em sua essência.

Mas é notável que todos os signos e as figuras do aprender que lhe são correspondentes ocupem um papel central no processo do aprendizado. Talvez olhar primeiramente não a arte, mas o amor, como figura do aprender violento, nos seja mais profícuo para entender a nova imagem do pensamento que essa nova imagem do aprender traz como consequência em seu bojo. Porque a atividade da filosofia será pensada, tanto por Proust como por Deleuze, como uma atividade em muito inferior ao amor e menos, talvez, profícua. Para ambos, os filósofos, como amigos da sabedoria, estão muito longe de compreender ou alcançar qualquer verdade. E se o estão é porque imaginam a chegada ao verdadeiro como resultado de uma vontade de verdade, de uma boa vontade, de um esforço ou de uma conversa produtiva.

Quem procura a verdade? E o que está querendo dizer aquele que diz: "eu quero a verdade?". Proust não acredita que o homem, nem mesmo um espírito supostamente puro, tenha naturalmente um desejo do verdadeiro, uma vontade de verdade. Nós só procuramos a verdade quando estamos determinados a fazê-lo em função de uma situação concreta, quando sofremos uma espécie de violência que nos leva a essa busca. Quem procura a verdade? $\mathrm{O}$ ciumento sob a pressão das mentiras do amado. Há sempre a violência do signo que nos força a procurar, que nos rouba a paz. [...] O erro da filosofia é pressupor em nós uma boa vontade de pensar, um desejo, um amor natural pela verdade. A filosofia atinge apenas verdades abstratas que não comprometem, nem perturbam (ibidem, p. I4-I5; os grifos são meus).

O que Proust fez e o que Deleuze quer recuperar da Recherche é isso que chamamos acima, de maneira um pouco livre, de imagem do pensamento. Trata-se de compreender como o pensamento se pensa a si próprio, como ele pensa sua própria atividade. Há algo que a imagem do pensamento da filosofia ignora e que é preciso recuperar: a violência, que desaparece em todos os discursos que primam pela boa vontade e pela troca pacífica de ideias. É como dizer: não é assim que se aprende; ou ainda: não é assim a maneira como os objetos do mundo se oferecem a nós, não é assim que os signos vêm ao nosso encontro, não é assim que percebemos a necessidade de buscar a verdade. Será por 
causa dessa nova imagem do pensar e do aprender que a defesa da filosofia atividade de busca da verdade diante da violência com a qual os signos do mundo perturbam e ao mesmo tempo produzem nosso pensamento - torna-se discurso contra a filosofia. O filósofo, nesse ínterim, não poderá mais ser o amigo da sabedoria. Será antes o amante e o artista.

Segundo Proust, os amigos são como espíritos de boa vontade que estão explicitamente de acordo sobre a significação das coisas, das palavras e das ideias; mas o filósofo também é um pensador que pressupõe em si mesmo a boa vontade de pensar, que atribui ao pensamento o amor natural do verdadeiro e à verdade a determinação explícita daquilo que é naturalmente pensado. Por esta razão, ao duo tradicional da amizade e da filosofia, Proust oporá um duo mais obscuro formado pelo amor e pela arte (ibidem, p. 28-29).

Resta ainda, contudo, compreender melhor o que significa não mais ser amigo do pensamento, mas seu amante. Fundamental entender também por que, havendo figuras - o amante e o artista - que dão conta da nova imagem do pensamento, seria necessário recuperar essa figura ilusória - o filósofo - e a imagem do pensamento a ele ligada: a filosofia. A pergunta a que essa nos leva é talvez desde sempre a mais inquietante: O que é isto - a filosofia?

\section{Idiota}

Esta é uma questão que enfrentamos numa agitação discreta, à meia-noite, quando nada mais resta a perguntar. Antigamente nós a formulávamos, não deixávamos de formulá-la, mas de maneira muito indireta ou oblíqua, demasiadamente artificial, abstrata demais; expúnhamos a questão, mas dominando-a pela rama, sem deixar-nos engolir por ela. Não estávamos suficientemente sóbrios. Tínhamos muita vontade de fazer filosofia, mas não perguntávamos o que ela era, salvo por exercício de estilo; não tínhamos atingido esse ponto de não estilo em que se pode dizer enfim: mas o que é isso que fiz toda a minha vida? (Gilles Deleuze; Félix Guattari, O que éa filosofia?)

III.I.

À difícil questão, uma resposta aparentemente simples: "a filosofia é a arte de formar, de fabricar, de inventar conceitos" (Deleuze; Guattari, 2000, p. 8). Simples, mas cheia de consequências. Criar conceitos não significa achá-los 
prontos. Conceitos não são "achados" ou "produtos". "Os conceitos não nos esperam inteiramente feitos, como corpos celestes. Não há céu para os conceitos" (ibidem, p. II). Não se pode chamar de filósofo alguém que não tenha criado seus próprios conceitos: um filósofo desse tipo "não valeria nada" (ibidem, p. I2). E não vale.

Criar conceitos não é algo como mais uma atividade dentre todas aquelas às quais a filosofia poderia se lançar, mas sim sua atividade específica. Decerto muitos campos quererão reivindicá-la. Contudo, há algo que é fundamentalmente distinto na criação filosófica que a diferencia da criação da arte, da ciência e do marketing (que também reivindica para si, não custa lembrar, o estatuto de "criador de conceitos"). A filosofia, como criação de conceitos, pressupõe a criação de um plano sobre o qual esses conceitos se organizam. Trata-se do plano de imanência de uma filosofia. A imbricação dos conceitos no plano não segue a estrutura de um quebra-cabeça. O que ocorre, na verdade, é o choque e sobreposição de estruturas que não podem ser pensadas separadamente (pensamento, ser e dúvida em Descartes; Deus, mônada e mundos possíveis em Leibniz...).

O plano é um recorte no caos. Há, no início, desordem; num certo momento, todavia, cada filósofo faz determinadas escolhas dentro dela e, com isso, começa a dar ao caos configurações, que oferecerão ao pensamento, mesmo dentro de certa ordenação, infinitas possibilidades, mundos possíveis. Assim, todo filósofo, a partir de um recorte determinado, trabalha os conceitos como unidades fragmentárias que tentam lidar com o caos. Caos que é originário e constitutivo ao pensamento, já que o fez nascer e que, ao mesmo tempo, permanece rondando-o e ameaçando-o com a desordem e a inconsistência. Tal é outra importante característica da filosofia: ela busca sempre criar a partir da violência do caos. Ao defender que os filósofos constroem os seus pensamentos a partir do caos, Deleuze opõe-se frontalmente à tradição, que tende a conceber o pensamento como antípoda da desordem, que busca dela afastar-se definitivamente através de estratégias como a sistematização e a fundamentação. O ato instaurador de uma filosofia - "lance de dados", como Deleuze o chamará muitas vezes - comporta muito de acaso e opcional. Decerto todo pensamento buscará fugir da desordem, mas isso não significa que o que origina a filosofia, sua "matéria", seja a ordem e que ela possa assegurar a todo o momento, ordenações que assegurem sua consistência.

Trabalhar com o caos não é o trabalho da ciência, que só começa a operar quando as coordenadas, que põem limite ao ilimitado, ou ao menos que tornam o ilimitado delimitável através da representação gráfica, começam a 
operar. As coordenadas cartesianas representam bem, nesse sentido, o trabalho científico: tudo agora está organizado, já sabemos com precisão que caminho tomar, mesmo se quisermos ir rumo ao infinito. Na filosofia isso não ocorre, como vimos. E isso porque ela trabalha com o pensamento ainda no interior do caos, liberto aos seus movimentos infinitos, em direções infinitas. A ciência, pelo contrário, torna todo movimento finito, precisamente localizável, remetendo-o a uma abscissa e a uma ordenada, para que o pensamento científico possa se desenvolver. A arte, por sua vez, não tem como pretensão última trabalhar com o caos, mas desenvolver percepções e afecções que afetem a alma, abrindo-a para a essência do que se repete sempre de maneira diferente.

Sobre o plano, dando vida aos conceitos, os filósofos criam personagens conceituais. A filosofia os conhece bem - Sócrates, o Sofista, o Estrangeiro, em Platão; Dioniso, o Nobre, o Escravo, em Nietzsche... Mas os traços podem ser também dinâmicos: dançar como Zaratustra, mergulhar como Melville. Ou jurídicos: já que "o pensamento não cessa de exigir o que lhe cabe de direito" (ibidem, p. 87), como sempre lembrará o tribunal da razão kantiano. Um filósofo é essa face estranha através da qual falam todos os seus personagens conceituais - tanto os simpáticos, aqueles que defendem sua filosofia, quanto os antipáticos, aqueles que precisam ser criados como contraponto violento do plano que é instaurado. "Dioniso se torna filósofo, ao mesmo tempo em que Nietzsche se torna Dioniso", e Platão, quem começou o grande jogo de encenações e máscaras, "se torna Sócrates, ao mesmo tempo em que faz Sócrates tornar-se filósofo" (ibidem, p. 80). Deleuze deixa de se tornar Deleuze: "eu não sou mais eu, mas uma aptidão do pensamento para se ver e se desenvolver através de um plano que me atravessa em vários lugares" (ibidem, p. 78). O pensamento deixa de ser nosso para formar sua própria imagem.

III.II.

Todo esse percurso para que possamos compreender melhor o plano sobre o qual nos movimentamos. Tendo entendido o esquema conceitual a partir do qual o texto opera, vejamos mais de perto um dos personagens antipáticos do plano de imanência de Deleuze e Guattari, em O que é a filosofia? - a figura do Mestre-Escola, do Professor, que se opõe ao Idiota, figura simpática do plano.

Decerto não é à toa que o primeiro exemplo que será invocado no texto para explicar o que é um personagem conceitual é o exemplo do Idiota. Que os antipáticos não nos ouçam, mas, por algum motivo, aparentemente a filosofia só 
pode começar por uma idiotice. A pergunta é sobre o cogito de Descartes - existiria algo entre o plano pré-filosófico e os conceitos filosóficos? Algum terceiro elemento? Haveria sim, e ali, em Descartes, toma a forma do Idiota, que diz o eu e propõe a extravagância do cogito. Mas por que extravagância?

O idiota é o pensador privado por oposição ao professor público (o escolástico): o professor não cessa de remeter a conceitos ensinados [...], enquanto o pensador privado forma um conceito com formas inatas que cada um possui de direito por sua conta (eu penso). Eis um tipo muito estranho de personagem, aquele que quer pensar e que pensa por si mesmo, pela "luz natural" (ibidem, p. 75-76).

O Idiota cria o conceito, enquanto o professor público, o escolástico, relembra, através de uma repetição que não é diferença, os conceitos criados pelos doutores da Igreja. Isso não basta ao Idiota - talvez sua idiotice consista precisamente em cometer a extravagância de "querer pensar e pensar por si mesmo". O "professor público", personagem antipático, é o antípoda do filósofo. Não quer e abomina criar. Insiste em se "remeter a conceitos ensinados", de maneira que não aprende. Foi necessário um Idiota, que começasse a se perguntar por coisas que para o professor nunca seriam alvo de dúvida - O que sou? O mundo existe? Deus existe? - para que a criação recuperasse sua força.

O Idiota surge para se opor à filosofia como doxografia - quer dizer, um conjunto de opiniões acumuladas, cada vez mais perfeitamente conhecidas, não é filosofia, pois não é uma atividade criadora.

É sempre a mesma melancolia que se eleva das Questões Disputadas e dos Quodlibets da Idade Média, em que se aprende o que cada doutor pensou, sem saber por que ele o pensou (o Acontecimento), e que se encontra em muitas histórias da filosofia nas quais se passa em revista as soluções sem jamais saber qual é o problema (a substância em Aristóteles, em Descartes, em Leibniz...), já que o problema é somente decalcado das proposições que lhe servem de resposta (ibidem, p. 97).

Todo conteúdo de manual não é parte da filosofia. Toda originalidade criativa de cada plano de imanência, deslocada de sobre o plano para o manual, perde sua força, porque deslocada do contexto problemático que lhe deu origem. O título da obra brinca justamente com essa redação de manuais que pode ser confundida com a criação de uma filosofia - O que é a filosofia? imita "ironicamente, desde o título, a linguagem dos manuais, dos livros da coleção Qu'est 
sais-je e dos prontuários de uso universal" (BIANCO, 2002, p. I96). A verdadeira história da filosofia, contrapondo-se a esse tipo de manual, pergunta-se pelo Acontecimento violento que levou à criação de cada plano de imanência.

Nesse sentido, o que pode significar aprender e ensinar filosofia? Aprender é aprender a criar, tornar-se progressivamente aberto para o caos e para a violência dos signos. Aprender também a impor um recorte no caos, ao mesmo tempo em que se mantém em aberto a possibilidade dos movimentos infinitos do pensamento. Ensinar, por sua vez, não será, de modo algum, passar em revista as soluções de cada filósofo, adquirir conhecimento de manuais, separando as respostas dos filósofos do trabalho da violência inerente ao corpo a corpo com os conceitos durante a construção de sua imagem do pensamento.

De muitos livros de filosofia, não se dirá que são falsos, pois isso não é dizer nada, mas que são sem importância, nem interesse, justamente porque não criam nenhum conceito, nem trazem uma imagem do pensamento ou engendram um personagem que valha a pena. Só os professores podem pôr "errado" à margem, e...; mas os leitores podem ter ainda assim dúvidas sobre a importância e o interesse, isto é, a novidade do que se lhe dá para ler (DELEUZE; GUATTARI, 2000, p. IOO).

No interior da atividade da filosofia, a caneta vermelha do professor não faz nenhum sentido. Cabe ao leitor, àquele que vai de encontro à criação filosófica, dar conta de saber se aquela imagem do pensamento vale ou não a pena. Isso nos encaminha para uma pergunta tanto mais interessante quanto aporética - se só o professor pode pôr errado à margem, pode o professor de filosofia fazer o mesmo...? É possível existir algo como um professor de filosofia...?

\section{Violência}

Com justa razão pode Sócrates dizer: sou o Amor mais do que o Amigo, sou o Amante; sou a arte mais do que a filosofia; sou a coação e a violência, mais do que a boa vontade.

(Gilles Deleuze, Proust e os signos)

Decerto o texto de Deleuze está bem longe de ser um texto teórico que nos oferece diretrizes práticas para o ensino de filosofia; já o dissemos, mas não custa reforçar: não é seu objetivo e só teríamos a perder buscando nele algo 
dessa natureza. Mas as perguntas - o que é ensinar filosofia? O que aprender com a filosofia? - não são questões somente pertencentes ao campo da didática e da pedagogia, mas ao fundamento da própria interrogação de natureza filosófica. Entretanto, a leitura de O que é a filosofia? dá a impressão de que tais questionamentos vão ficando em suspenso. O caminho que o texto de Deleuze nos sugere - abrir o aprendiz à violência dos signos, abrir-nos a tal violência - nos coloca em mais uma aporia: como ensinar, concretamente, algo desse tipo, algo como essa abertura, algo como essa violência; e como convencer(-nos) a entregar-se à violência do pensamento? "O que eu ganho com isso?" E qual seria o papel da história da filosofia, para além da coletânea de problemas descontextualizados?

Há algo que precisa ser conciliado; algo de que o próprio texto de $\mathrm{De}$ leuze e Guattari busca dar conta: trata-se da conciliação entre a violência criadora e o conhecimento legado pela tradição. Ambos são fundamentais na formação da imagem do pensamento de um filósofo. De maneira mais ampla, esse movimento, da rememoração do que se passou, como vimos na monografia sobre Proust, é parte fundamental do processo de aprendizagem. Mas o aprendizado está inexoravelmente ligado também à rememoração de algo que aconteceu na história da humanidade, reencontro com o patrimônio legado pelos que nos antecederam; em filosofia, o patrimônio conceitual da história do pensamento.

E, tendo em vista que já há um grande plano de imanência sobre o qual as diferentes filosofias vão criando seus diversos planos e que, por isso, dá corpo a uma tradição de problemas herdados sempre de planos anteriores, não temos muita escolha: cada filosofia e cada imagem do pensamento se constituem como bricolagem de conceitos de outros pensadores. Mas essa aparente ausência de escolha é o que torna nossa escolha possível. Pois não se trata, propriamente, dos mesmos conceitos, pois esses estão agora sobre um novo plano. Criar é reterritorializar, deslocar, "roubar" algo que fazia parte de outros planos: pensamento em Descartes não é pensamento em Kant; democracia em Platão não é democracia em Habermas. O nome de batismo do conceito se mantém, mas muito muda.

O que poderia significar, portanto, ser aluno e professor sobre esse novo plano? Ora, de maneira análoga ao que aconteceu com a imagem da filosofia, a figura do professor precisa da crítica da figura do professor para se constituir; tratar-se-á agora de outro professor - outro plano, outro conceito. Aluno e professor serão ambos amigos da filosofia, mas não no sentido de uma amizade fundada na "comunidade de ideais e sentimentos" (ibidem, p. 28). Trata-se agora da rivalidade dos amigos, que, ao ver de Deleuze e Guattari, 
teria fundado a verdadeira amizade filosófica. Amizade que ocorre somente no interior do campo da disputa, do agon.

E que o amigo faz? Cria situações para que ocorra aquilo que possibilita o aprendizado: os encontros, que trazem em si a necessária violência. Como outrora já faziam: "o demônio socrático, a ironia, consiste em antecipar os encontros. Em Sócrates, a inteligência precede os encontros; provoca-os, suscita-os, organiza-os" (ibidem, p. 95). O que é irritante nesse incômodo amigo que nos é Sócrates é que ele nos leva ao encontro da violência a todo o momento; planeja, consegue. Obriga-nos a sair de terra firme.

Pois sair da terra firme é precisamente o que define o aprendizado. Só locomovendo-se, buscando novos espaços, novos planos, é possível que aprendamos. Desterritorializar-se é o traço da nossa espécie, é o traço do aprendizado. E desterritorializar, conceito sempre recorrente em "Deleuze-Guattari", é aqui a capacidade de dar nova significação a um elemento através do seu deslocamento ou alteração de posição em relação ao locus onde estava firmado.

Com mais forte razão, o hominídeo, desde o seu registro de nascimento, desterritorializa sua pata anterior, ele a arranca da terra para fazer dela uma mão, e a reterritorializa sobre seus galhos e utensílios. Um bastão, por sua vez, é galho reterritorializado. É necessário ver como cada um, em toda idade, nas menores coisas, como nas maiores provações, procura um território para si, suporta ou carrega desterritorializações, e se reterritorializa sobre qualquer coisa, lembrança, fetiche ou sonho (DELEUZE; GUATTARI, 2000, p. 83).

A criação filosófica não pode ser pensada sem essa reterritorialização, sem essa espécie de nomadismo ativo. Por isso não há percurso filosófico que não seja o percurso de um aprendizado. Não nos resta outra escolha verdadeira a não ser escolher pela violência. A fuga é impossível. Decerto sofreremos - nossos seres amados podem nos enganar, nossos amigos nem sempre serão simpáticos, nossos planos nem sempre serão firmes - e, quando menos esperarmos, a bússola da razão girará descontroladamente, em pleno mar, sem norte.

A pergunta mais digna, talvez, com que poderíamos finalizar a apresentação desses "materiais" sobre aprendizado e violência, é justamente a pergunta mais digna: para que, então, a filosofia? Para que, então, a violência do pensamento? Perguntar-se isso, não como exercício de estilo, nem como resposta a um chiste, talvez consista na mais violenta das atividades. Que não se enganem os apologistas da paz: pois pensar não é fugir da violência, mas conhecer bem com que violência queremos... jogar. 


\section{Referências bibliográficas}

ALliEZ, Eric (Org.). Gilles Deleuze: uma vida filosófica. São Paulo: Editora 34, 2000.

BADIOU, Alain. Deleuze: o clamor do ser. Rio de Janeiro: Zahar, I997.

BIANCO, Giuseppe. Gilles Deleuze educador: sobre a pedagogia do conceito. Educação \& Realidade, Porto Alegre, v. 27, n. 2, p. I79-205, jul./dez. 2002.

- Otimismo, pessimismo, criação: pedagogia do conceito e resistência. Educação e Sociedade, Campinas, v. 26, n. 93, p. I289-I308, set./dez. 2005.

DELEUZE, Gilles. Diferença e repetição. Lisboa: Relógio D’Água, 2000.

. Em quê a filosofia pode servir a matemáticos, ou mesmo a músicos: mesmo e sobretudo quando ela não fala de música ou de matemática. Educação \& Realidade, Porto Alegre, v. 27, n. 2, p. 225-226, jul./dez. 2002.

. Proust e os signos. Rio de Janeiro: Forense Universitária, 2003.

; GUATTARI, Félix. O que é a filosofia?. São Paulo: Editora 34, 2000.

GIL, José. Ele foi capaz de introduzir no movimento dos conceitos o movimento da vida. Educação \& Realidade, Porto Alegre, v. 27, n. 2, p. 205-224, jul./dez. 2002.

HARDT, Michael. Gilles Deleuze: um aprendizado em filosofia. Rio de Janeiro: Editora 34, I996.

MACHADO, Roberto. Deleuze: a arte e a filosofia. Rio de Janeiro: Zahar, 2009.

PRADO Jr., Bento. A retórica de Rousseau e outros ensaios. São Paulo: Cosac Naify, 2008.

. Erro, ilusão, loucura. São Paulo: Editora 34, 2000.

PROUST, Marcel. À sombra das raparigas em flor. São Paulo: Globo, 2007.

. No caminho de Swann. São Paulo: Globo, 2007.

O caminho de Guermantes. São Paulo: Globo, 2007.

Eraldo Souza dos Santos - Graduado em Filosofia pela FFLCH - Universidade de São Paulo.

eraldo.souza.santos@usp.br 